\title{
How leaders can manage the disruption caused by the
}

\section{pandemic [version 1; peer review: 1 approved with}

\section{reservations, 1 not approved]}

\author{
Mathew Donald
}

Department of Management, Charles Sturt University, Bathurst, NSW, 2795, Australia

V1 First published: 22 May 2020, 2:30

https://doi.org/10.35241/emeraldopenres.13713.1

Latest published: 22 May 2020, 2:30

https://doi.org/10.35241/emeraldopenres.13713.1

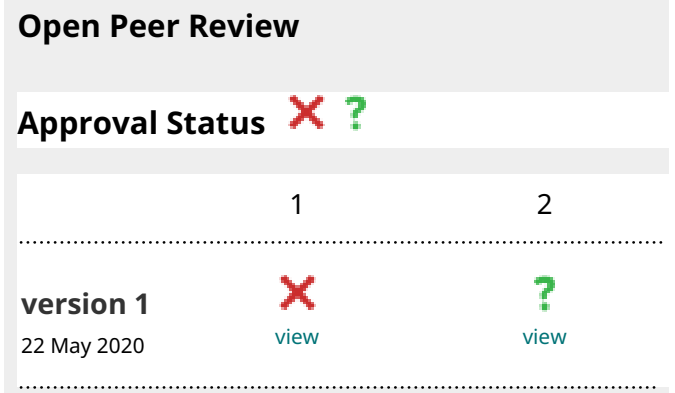

1. Alberto Romero-Ania, Rey Juan Carlos University, Madrid, Spain

\section{Alessandro Margherita, University of} Salento, Lecce, Italy

Any reports and responses or comments on the article can be found at the end of the article. 
Keywords

pandemic, disruption, management, leadership, organization

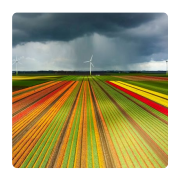

This article is included in the Responsible

Management gateway.

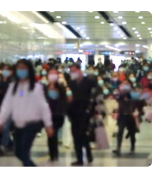

This article is included in the Coronavirus

(COVID-19) collection.

Corresponding author: Mathew Donald (matdonald1@hotmail.com)

Author roles: Donald M: Conceptualization, Methodology, Writing - Original Draft Preparation, Writing - Review \& Editing

Competing interests: No competing interests were disclosed.

Grant information: The author(s) declared that no grants were involved in supporting this work.

Copyright: $(2020$ Donald M. This is an open access article distributed under the terms of the Creative Commons Attribution License, which permits unrestricted use, distribution, and reproduction in any medium, provided the original work is properly cited.

How to cite this article: Donald M. How leaders can manage the disruption caused by the pandemic [version 1; peer review: 1 approved with reservations, 1 not approved] Emerald Open Research 2020, 2:30 https://doi.org/10.35241/emeraldopenres.13713.1

First published: 22 May 2020, 2:30 https://doi.org/10.35241/emeraldopenres.13713.1 


\section{Research approach}

A literature review of the organisational structures and processes was firstly undertaken by this research in order to explore and critique the current organisational structures with respect to the significant changes that have been brought on by the Covid-19 pandemic. A review of the leadership topic has also been conducted as part of that literature review as it is considered that the pandemic may require alternate leadership skills due to its sudden and unpredictable impacts. This theoretical research has been undertaken as a means to discover and recommend new organisational design and leadership in the context of a specific pandemic disruption that emerged in 2020.

Due to the time and context of this research it has not reviewed real cases, nor has it involved survey or interview of organisations to see what may be happening during the pandemic. It is considered that any benefits of real case studies and survey will not be fully understood until later in the pandemic so were not appropriate at this early stage.

This research is aimed at providing the reader with relevant theoretical guides towards organisational management that may be used during and post the pandemic. Organisations working through social distancing, government restrictions, unemployment and customers under cash stress in 2020 may find that it not possible to return to their pre-pandemic operations, where this research may provide useful information and insights to be used in organisational recovery efforts. This research began with a review of the literature so as to understand the topics with respect to the recent research, as a way to provide the insights for those managing organisations of the future.

\section{Literature review}

A review of leadership ${ }^{1}$ was conducted over the literature as a means to understand the topic of change, leadership and management more deeply and as a way of critiquing the current practices against the backdrop of a pandemic type disruption. Pandemic planning has been recommended for those seeking to modernize and prepare their organisation for fast moving, sudden and unpredictable disruptions (Donald, 2019). The nature of this literature review is important as any disruption, especially a pandemic, has the potential to significantly disrupt the traditional organisational models (Basile \& Faraci, 2015; Donald, 2019). Past research below has reviewed business systems, organisational environments, processes and structures, in the pursuit of understanding the future of organisational models in a disruption.

Organisations may need more agility to operate in a disruption environment (Denning, 2018; Donald, 2019) as many of the traditional business systems may slow and inhibit adaption. Change is no longer a one-off event, rather is now an almost continuous process (Burnes, 2004; Král \& Králová, 2016), where the ability to adapt may be a survival necessity in the future (Donald, 2019). It may no longer be appropriate to imagine change as a staged process as once was the case in early

${ }^{1}$ Research key words used were leadership, innovation, business structures, business processes, matrix, product structure, departmentalisation, disruption. resistance research (Lewin, 1945). Organisational structure variations may even be a measure of change (Král \& Králová, 2016). Whilst communication is considered one important element of change (Král \& Králová, 2016), where it is but one of at least seven other change factors (Donald, 2017; Donald, 2019).

One may consider that corporate controls are often supported by various corporate structures, the controls may also need to be adjusted as organisations change (Maciejczyk, 2016). Many of the current organisational structures used by business have goals of improving outcomes and supporting strategy. The common matrix structure, for instance, originated as one to improve the functional and operational variability (Peters, 1993). Various factors including strategy, environment, technology and organisational size influence organisational structures (Daft, 2012; Král \& Králová, 2016), where these may influence even technological innovation (Hu, 2014). Structures are not standardized, allowing significant variation between organisations, so some may be centralized yet allow decentralisation in various operational matters (Romelaer \& Beddi, 2015). There is great variation across country of origins and those operated globally (Heenan \& Perlmutter, 1979; Perlmutter, 1969; Romelaer \& Beddi, 2015). It is recognised, despite the variability, that there are several common structure types, including matrix structure, divisional structure, product structure and area structure (Romelaer \& Beddi, 2015; Stopford \& Wells, 1972; Williams et al., 2016).

There is no fixed business structure, where they can vary over time and inside markets along the structures of functions, departments, regions, product or matrix (Williams et al., 2016), or even functions, divisions and matrix (Maciejczyk, 2016). Structural design often varies based on management and market environment (Maciejczyk, 2016; Williams et al., 2016) or even management philosophy and perspective. Other control systems that management use to run their organisations include that of job descriptions, pay rates and authorities (Guadalupe et al., 2013).

Interconnected trade, otherwise named as globalisation, can emerge as unstable or chaotic (Roome, 1998; Roome, 2011), with great uncertainty and risk (Donald, 2019). Even sectors that were once the domain of government alone have changed since the emergence of globalisation (Roome, 2011). In a market response, prompted by increased efficiencies and profits, some organisations have outsourced their non-core efforts (Sarmiza, 2010). It is now clear that globalisation benefits have not been uniformly distributed, where there has been increases in world migration and refugees (Roome, 2011).

The benefits of globalisation appear to have presented in the larger, more powerful brands (Roome, 2011), including those that own systems rather than products and assets (Roome, 1998; Roome, 2011). Work practices have also divided in globalisation where there has been a divergence between worker rights, split between those full time employed and the growing casualization of the work force (Ekberg et al., 2016; Virtanen et al., 2005). It is clear that competing on a global basis that casuals have been utilized in the pursuit of flexibility (Blanck, 2014; Schur et al., 2013; Virtanen et al., 2005). 
The modern multinational structure is complex, including many interconnected relationships (Ghoshal \& Westney, 1993; Romelaer \& Beddi, 2015). Organisational design elements of power, control, strategy and knowledge are inadequate, so a broader model with increased elements may be required (Romelaer \& Beddi, 2015). The matrix structure may be too slow (Anderson, 1994), despite its broad appeal and use in technical organisations (Anderson, 1994; El-Najdawi \& Liberatore, 1997; Kuprenas, 2003). Other replication models, like IKEA, allow modifications through a process of learning and local variations derived from regional differences (Jonsson \& Foss, 2011). To achieve an expansive model with replication, organisations use process codification and detailed instructions (Jonsson \& Foss, 2011).

Corporate social responsibility (CSR) and ethics may harm business models (Albach, 2005; Albach, 2007), or be quite be contrary to capitalism (Friedman, 1970), yet CSR and ethics may be an essential for globalisation (Pies et al., 2010). Staff may be more appropriately guided with ethics when change is constant and written rules are redundant (Donald, 2019). Despite the debate, CSR is not yet an agreed concept as it has many definitions (Carroll, 1999; Dahlsrud, 2008; Guthey \& Morsing, 2014). Whilst CSR may be characterised with elements of adaptability and resilience (Guthey \& Morsing, 2014), others portray this as being useful to challenge dilemmas and tradeoffs, where any divergent may be useful for society (Guthey \& Morsing, 2014; Margolis \& Walsh, 2003).

A pandemic, or other changing environment, may increasingly challenge management, so requiring new relationships with flexibility and credibility (Juras et al., 2014), or where creativity and innovation may enable create flexibility and credibility (Donald, 2019). Informal systems may be useful for startups, yet control systems are often adopted as organisations grow (Davila \& Foster, 2007), where startup Chief Executive Officers may find the traditional control systems too restrictive (Davila \& Foster, 2007). Traditional organisations may use gating systems to control and improve project success, yet may need amending to cope with a faster organisational speed or adaptability (Cooper, 2017). So in a pandemic, with great changes in government policy over time, an iterative rather than a fixed model, may be more useful with unison multiple cycles that are no longer sequential (Cooper, 2017).

Organisations are made up of more than merely control systems and structures, where other factors may need to be included, where authority and accountability alignment may be beneficial (Arya et al., 2007; Bedford et al., 2016; Giraud et al., 2008; Jevtić et al., 2018; Merchant \& Otley, 2006). Beyond the mere structures and processes of an organisation it is clear that leadership is a significant change factor (Donald, 2016; Donald, 2017; Donald, 2019) with others. Leadership can have positive organisational effects, where improving management skills may influence competition and co-operation (Lado et al., 1997; Strese et al., 2016). Organisational formalisation is associated with positive effects, yet centralisation may yield negative effects and co-operation or competition may yield improved financial results (Luo et al., 2006; Strese et al., 2016).
This literature review indicates that the controls and structures may be overly controlling for a faster, more unstable pandemic environment. The future organisational platforms may need a redesign if organisations are to respond to the post pandemic environment that has emerged from globalisation, the internet, technology and social media (Donald, 2019). The following section discusses the gaps identified from this literature review.

\section{Gaps in the literature}

Many of the past organisational models are based on a management control or power basis, each aimed at delivering consistency, quality or growth. Whilst original change research by Lewin (Lewin, 1945) assumed management control, the linear change assumption in Lewin's work may be too simple for this more complex environment (Dent \& Goldberg, 1999; Donald, 2019). Whilst control may have been essential to the structures of the past, centralisation may have negative effects, while co-operation and competition may improve results (Luo et al., 2006; Strese et al., 2016). Multiple structural types exist and may be altered regularly irrespective of the design being that of the matrix, the divisional, functional, the regional or product (Maciejczyk, 2016; Williams et al., 2016). Whilst structures may allow flexibility (Maciejczyk, 2016; Williams et al., 2016), they have been used for control, power, or for expansion (Jonsson \& Foss, 2011). There appears to be insufficient research using broader organisational criteria, as much of the existing research has been based on control or flexibility (Stverkova \& Pohludka, 2018).

Performance measures are widely used in business, so there is potential to research using those metrics in future research over alternate structures and processes (Kuprenas, 2003) in a post pandemic environment. As the post pandemic environment is faster and more unpredictable, future research may find it useful to adopt and compare alternate criteria such as adaptability, creativity and speed (Donald, 2017; Donald, 2019). Whilst formalisation may yield benefits to an organisation, centralisation does not (Luo et al., 2006), in a variable setting of a pandemic it may be useful to compare differences and effects of formalisation versus centralisation.

Whilst a gating system may have traditionally been used to control projects, it may be too formal and slow for almost constant change, the organisational models may need to adapt to the increased pace and adaptability (Cooper, 2017), especially during a pandemic. There appears to be little modern research around how organisations may already be emerging to respond to the new pandemic age environment. Additional criteria to analyse and measure organisations in this pandemic environment may be useful.

\section{Research criteria and limitations}

Organisational design has been researched with assumptions around management control based on their power, control and status. The new age business environment that is faster, more uncertain, less predictable and consequentially more risky than previous times (Donald, 2019), including a pandemic, perhaps is no longer appropriate for this new age. This research has not performed case studies or survey, rather it has removed management centricity, seeking to recommend a new business model, one more 
useful for the post pandemic new age. It is possible, due to their controls and rules base, that traditional management models may have limited creativity, critical thinking and flexibility. It may be important to remove the management control and power in order to enable an organisation to adjust for the pandemic environment.

Based on the literature review above this research has contemplated criteria that will be useful for future research as well as for the practitioner. Organisational design is usually not standard, often defined based on the circumstance, market position or by specific management criteria, each varying over time. No two organisations are likely to be the same at any point in time, even if they compete and exist in the same market, so this research has sought factors that may be useful in the pandemic new age, including its fast pace with great uncertainty. The following findings and related model are based on the literature review above, where the proposed framework is based on principles that may be tested and trialled by academics and practitioners alike in the future.

\section{Findings}

The above research has discussed how the past array of organisational structures and processes may no longer be appropriate for a globalised, disruptive environment (Donald, 2019). Whilst some organisations already allow local cultural and customer differences in regions (Jonsson \& Foss, 2011), most policies, processes and structures are premised on reductions in variation and to control (Maciejczyk, 2016). Whilst efficiencies may result from control and standardisation, the mechanisms of control have the potential to restrict creativity and critical thinking. The new age of pandemic with its faster, less uncertain and unpredictable nature may require deeper thought, broader ideas and multiple opinions as the situation is new and untried. It may be imperative for organisations to deploy a range of issue identification and assessments when change is unpredictable and uncertain.

Organisational structures may be assessed during times of change based on their openness, including elements of vision and innovation (Nisar et al., 2016). As was seen across the world in March 2020, even large successful organisations can quickly reduce size and value in such disruption. An example from the last twenty years is that where Kodak changed from a world picture printer to that of almost no value through the digitisation of photography (Donald, 2019). A key contributor to the loss in Kodak value may have been structure, process strategy and management strategy.

As discussed earlier, global diverse organisations may allow individualised strategies based on local sales, structures, finance and marketing influences (Alford \& Greve, 2017; Porter, 1996; Stverkova \& Pohludka, 2018), yet the structures are a choice of management (Romelaer \& Beddi, 2015) and may vary based on adaptability, innovation and scale (Kim \& Utterback, 1983). Whilst control may be the primary objective of structures, it has also been linked to quality (Gokpinar et al., 2010). New sources of data analysis over organisational models may be required as the old tools may be too restrictive when executives have changing needs (Cheung \& Babin, 2006), especially in a pandemic when rules vary regularly between countries and regions.
Future organisational control systems understanding may be improved if there is authority and accountability alignment (Arya et al., 2007; Bedford et al., 2016; Giraud et al., 2008; Jevtić et al., 2018; Merchant \& Otley, 2006) in improving organisational results (Daft et al., 2010; Jevtić et al., 2018; Khandwalla, 1973; Mintzberg, 1979; Simons, 2005; Simons, 2013). A cohesive overriding force may enable adaptive and fluid organisations to perform with reliability and reduce issues in organisational change (Grabowski \& Roberts, 2011). Whilst some structures may change in response to customer circumstances (Homburg et al., 2002), others may question the classical product and geographic models (Gebauer \& Kowalkowski, 2012). Whilst structure may be important to stability and control, it is worth remembering in a disruption that too many changes may lead to instability and reduced organisational effectiveness (Rapoport, 1989), or loss of trust in leaders (Donald, 2019)

Whilst many the primary corporate goal may be that of financial returns (Beets, 2011), there is a variety of secondary goals (Beets, 2011; Friedman, 1970; Grubbs, 1998; James \& Rassekh, 2000; Kamani, 2010; Manne, 2008; Silver, 2005). In the emergence of larger organisations tensions have often grown between the responsibilities of functional and operational management (Quail, 2008), that may need resolution in new models of the future. A comprehensive model of the multinational, with more elements is likely to be required for complete understanding of the modern organisation (Romelaer \& Beddi, 2015).

Traditional organisational structures may have served business well over the past fifty or more years, yet they are not without criticism or issues. Despite the perceived benefits, many matrix structures still result in confusion over roles and responsibilities (Johns, 1999; Kuehn et al., 1996), slower results and conflict (Kuprenas, 2003), and ambiguity or low efficiency (Goold \& Campbell, 2003). Power and responsibility can occur in a matrix structure, despite the perceived benefits of that structure (Anderson, 1994). Disruption (Donald, 2019) may result in a revolution of a kind, resulting in a complete adjustment to corporate structures if they are to survive and adapt (Stverkova \& Pohludka, 2018). The past structures may be inadequate to resolve the emerging issues over economic distribution, power and the environment (Roome, 2011), and even a pandemic, and whilst structure may be important to stability and control, it can lead to instability and reduced organisational effectiveness (Rapoport, 1989).

The matrix organisation appears to suffer less issues than the alternate structures despite its relatively higher complexity, potentially due to the way processes are varied (Rapoport, 1989). So a key challenge for management is to design a structure that meets the organisational strategy and returns whilst seeking to reduce the negative effects from any change (Rapoport, 1989). It has been argued that goal orientated functional organisations may be more able to adjust structures with relative stability (Rapoport, 1989). Knowledge and technology sharing can assist in developing innovative business models (Guan \& Huang, 2014), so innovation can be achieved if training is included ( $\mathrm{Hu}, 2014)$. As discussed above, ethics, society and community in future organisations may 
improve or reduce traditional organisational power (Beets, 2011), while training may also improve matrix structures (Kuprenas, 2003). In a changing environment some have argued that new governance is required (Donald, 2019; Roome, 2011), so it may too be useful in a pandemic that is dictated by ever changing government policies and rules.

The business leader should not be exclusively considering structure for improvements in a pandemic as flexible working arrangements also assist in the pursuit of efficiency, arising from additional flexibility and cross-skilling (Ekberg et al., 2016), where efficiency is also linked to the choice of structure and design (Basile \& Faraci, 2015). In the current pandemic, organisations may be incapable of keeping up the old control processes like documentation and training, so in a faster disruption environment higher level advice systems like ethics may be more useful (Donald, 2019). CSR may be useful with its connection between organisation and society values, combined with its elements of adaptability and resilience (Guthey \& Morsing, 2014).

As the world has had little experience in pandemics of recent times, new creative solutions may be required to survive and thrive, where innovations include new ways of working (Basile \& Faraci, 2015; Hamel, 2006), new processes and structures (Basile \& Faraci, 2015; Vaccaro et al., 2012), including administration (Damanpour, 1987; Pisano, 1996), management (Basile \& Faraci, 2015; Birkinshaw \& Mol, 2006; Hamel, 2006; Markides, 1997) and even organisation (Basile \& Faraci, 2015; Damanpour, 1987; Damanpour \& Aravind, 2011; Damanpour \& Evan, 1984).

The traditional risk registers used by organisational management were useful in preparing for reasonably predictable risk, yet in a pandemic risk and options are hard to predict, so may transcend markets and industries, where even the unlikely can occur suddenly (Donald, 2019). The proliferation of the internet, email and social media now transmits information instantly around the world without filtering or analysis in many cases. The old risk register does not appear to be appropriate when pandemics emerge, rather more creative and critical thinking is required in disruption (Donald, 2019).

As discussed above any new organisational model should not be based on management power, control or even efficacy, as the unpredictable nature in a pandemic may require frequent inefficient adjustments in order to survive and thrive. Any new model needs to be flexible, as pandemic policies will be variable, so any new model should not prescribe structures and processes or even roles. The goals of organisations may remain with their financial requirements yet may need to attempt to achieve societal goals with additional innovation, speed and adaptability. This research proposes that a new model proposed should emerge with an expanded notion of CSR. Flexible adaptation criteria may be better at measuring organisational success than merely the old financial systems, as any strategy and long-term goal can quickly be made redundant in pandemic changes. Even the product or service being offered may quickly be fundamentally changed when unpredictable pandemic changes arise, so it may be unfair or inappropriate to measure and reward merely on financial or strategic grounds.

Innovation, speed and organisational adaptability are proposed as two additional measures for any new organisational models. In the new model, the traditional manager and leader roles will likely require new skills to be able to influence and change an organisation quickly, yet not lose the trust or engagement of its key staff and broader stakeholders. Organisations may not currently measure and value organisational innovation, speed and adaptability, yet those measures may be more important in the pandemic future rather than merely financial outcomes alone. Essentially investors exist to achieve returns, where the fixed measure of budget or market forecast may no longer be an appropriate measure of their performance when changes are interconnected beyond the control of the management.

Furthermore, a new model is proposed for the post pandemic age, one that seeks to list key criteria for the achievement of four business measures of this new age. The achievement of innovation may be critical to find solutions that are different or superior to competitors, so will require creativity with flexibility in order to react and adapt to ongoing change, especially if not within the control of management. Whilst management should be responsible for identifying new, sudden and unpredictable change, any notion of fixed goal achievement is unlikely in a pandemic as government policy is so variable and unpredictable. It may be that skills for management of the future should include early change identification, options and critical thinking. The new organisational model proposed in this research is shown in Figure 1.

This new model in Figure 1 does not prescribe processes, structures or governance, leaving the exact form to management to decide based on their requirements and situation. Remaining with the traditional strategy, hierarchical structures, written processes and financial targets may simply be too prescriptive and limiting in a pandemic, as change is so uncertain, unpredictable and risky. For flexibility it is argued that roles and responsibilities should not be overly prescriptive either, as large documents may often not be used anyway (Goold \& Campbell, 2003), so it may be more important to show the purpose of a role (Goold \& Campbell, 2003; Merton, 1968), or an understanding of disruption (Donald, 2019). The new organisational model proposed in this research sets the measures for organisational success yet allows for flexibility within the model to achieve those goals, as in disruption, like a pandemic, structures, processes and stakeholder involvement may be under constant change. It is perceived that more creative solutions may emerge if roles and responsibilities, accountabilities less defined in the new age.

\section{Practical applications, future study}

This research has proposed a new organisational model that allows for diversity and creativity, where the practitioner is allowed flexibility in design but remains responsible for the model and its measures, albeit the measures expanded for the new age. The model proposed in Figure 1, emerged out of the literature review, formed as an early proposal for organisations wishing to adapt to a very risk and unpredictable post 


\section{Post Pandemic Proposed Organisational Model}
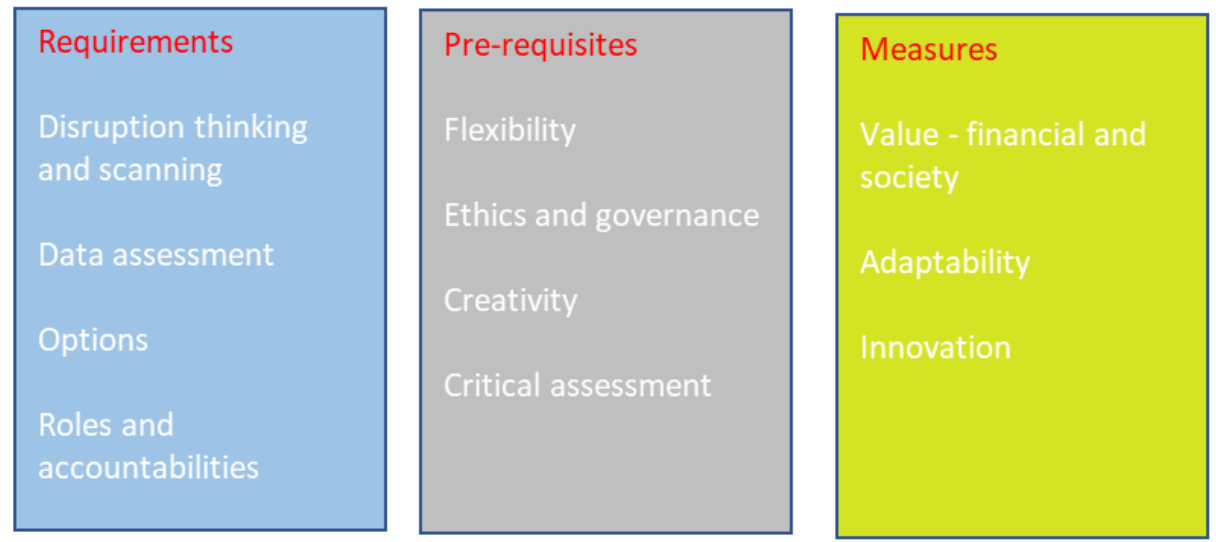

Figure 1. Proposed new age organisational model.

pandemic world business environment. The traditional models of setting strategy, annual budgets and financial measures appear to be too rigid, lacking flexibility and creativity when unpredictable pandemic and post pandemic policies emerge. Entrepreneurs may have the requisite creativity to design new solutions, yet they need to still engage stakeholders with close staff relations, trust and engagement as each has been linked to change success (Donald, 2019).

Traditional organisational models rely upon governance through reporting of deviations and inefficiencies, yet governance is often retrospective and slow in larger organisations, occurring well after any decision-making process. This is not to push governance into the irrelevant, rather it may hold higher relevance counter the creativity and risk profiles of the creative and entrepreneurial (Donald, 2019). Governance may need to be closer to decision making timing, where it is involved in the development of options and their critical assessment before decisions are made (Donald, 2019). Of course, if governance is to be closer to decision makers their independence can be compromised. Although there are benefits of real time independent advice that may outweigh independence issues as closer governance, in real time may be beneficial in avoiding the illegal or unethical actions. The measures for organisational success are no longer purely financial in this proposed model, rather ethics and society value need to also balance with the creative and innovation. Governance should not be limited to pure financial audits, rather it should provide independent advice against all four of the measures proposed in this new model (Figure 1).

For managers and leaders trained in past times it may be confronting or quite difficult to contemplate a model without management centricity, power and control. The traditional model was based on expectations that the business environment was reasonably predictable and controllable, where the manager was in control with great knowledge to solve and propose solutions. In the new age with its faster, less uncertain and riskier environment, management is unlikely to be all knowledgeable, nor be the source of all the creativity and best options. Management will need the support and skills of staff and the broader stakeholders if they are to quickly identify issues and best fit solutions, management may now be the facilitator of the flexible and the adaptive rather than merely being the controller of the financial outcomes.

Furthermore, the new model removes the notion that management make decisions independently, where they merely seek to consult or communicate after decisions are made. The old process is considered to be too slow and may inhibit trust, so it may be advantageous to share the environment and broader business issues before decisions are made in this new age. Inclusion and consultation occurring as decisions are made may be more engaging, as staff, customers and suppliers are allowed to have more information and understanding of the issues. Of course, these new relations need to be genuine, where staff and others are allowed to give negative feedback or make suggestions and assessments without fear of retribution or criticism. Trust and engagement have both been closely linked to a number of other change factors (Donald, 2017; Donald, 2019), so in constant change a broad set of factors should be included in the new processes.

It is important to consider how divergent this proposed model will be for those trained in leadership and management in past times. Managers and leaders trained in the past may not fully appreciate the pandemic age as it is fast paced, uncertain and risky, where they may ignore the pandemic and continue to operate using power and control modes of the past. Organisations that do not seek to inform, train and increase knowledge on disruption, pandemic in particular, may find their staff disillusioned, 
resistant towards the goals and operations of a new model. Innovative business models have been associated with knowledge and training (Guan \& Huang, 2014), and innovation may improve efficiency and novelty models where training is included (Hu, 2014). Organisations should seek to modernise and adapt in a pandemic, seeking to be faster and more creative than they may have been in pre-pandemic times.

A pandemic, whilst full constant change (Donald, 2019), it is not all pessimistic and poor, as new transactions, new tools and opportunities will likely emerge to solve social distancing, poorer economics and unemployment that has resulted. Such new opportunities will likely emerge with new technology, artificial intelligence and a continued broadening interconnectedness from globalisation. A broad and multiple dimension change approach is more likely required to cover all the issues that may arise, as shown in Figure 1, the new model is not prescriptive. Organisations that are unable to adapt or transition to a new creative and innovative model may find their competitors adapting and innovated more often and earlier than the traditional models.

\section{Contribution to pandemic preparedness}

The new age of pandemic is faster, more unpredictable and more uncertain than in the past, where new situations, new transactions and new possibilities may emerge with little predictability (Donald, 2019). Organisational survival may depend on managers with skills in early identification of change issues, good at analysis with critical thinking of a range of options. Management and leadership of the future will be challenged like never before as technology moves from the change itself to the enabler of faster and more uncertain change that may be necessary as the pandemic evolves.

Management centric models of power and control may now be redundant as future managers are unlikely to be knowledgeable on all organisational effects. Risk identification is no longer the domain of management, rather they will now be more dependent on their staff, customers and suppliers to identify risks and opportunities and solutions. Organisations of the future will need to foster skills of creativity, inclusion, openness and ethics in their teams, skills that may not have been as important in the past power and control models.

The case for less management centric organisational models has been made in this research, a new model is proposed to produce faster adaptation to risks and opportunities. The model proposed in this research, includes new measures beyond a mere financial outcome, so arguing for flexible adjusting targets over a more traditional fixed budget. It is recommended by this research that all stakeholders be included in decision making as a way to create new ideas, improve trust and to build understanding and engagement. The pandemic environment is like no other in the past one hundred years, so management are unlikely to be prepared and experienced for the new uncertain world ahead, where a new adaptive and creative model may be just the improvement required to survive and thrive in this new age.

\section{Data availability}

All data underlying the results are available as part of the article and no additional source data are required.
Albach $\mathrm{H}$ : Betriebswirtschaftslehre ohne Unternehmensethik. J Bus Econ. 2005; 75(9): 809-831.

Reference Source

Albach $\mathrm{H}$ : Betriebswirtschaftslehre ohne Unternehmensethik - Eine

Erwiderung. J Bus Econ. 2007; 77(2): 195-206.

Reference Source

Alford J, Greve C: Strategy in the Public and Private Sectors: Similarities, Differences and Changes. Adm Sci. 2017; 7(4): 35.

Publisher Full Text

Anderson RE: Matrix redux. Bus Horiz. 1994; 37(6): 6-10.

Publisher Full Text

Arya A, Glover J, Radhakrishnan S: The Controllability Principle in Responsibility Accounting: Another Look. In: F. G. R. Antle, \& P.J. Liang (Ed.), Essays in Accounting Theory in Honour of Joel S. Demski. New York, NY: Springer Nature. 2007; 183-198

Publisher Full Text

Basile A, Faraci R: Aligning management model and business model in the management innovation perspective. J Organ Chang Manag. 2015; 28(1): 43-58. Publisher Full Text

Bedford DS, Malmi T, Sandelin M: Management control effectiveness and strategy: An empirical analysis of packages and systems. Account Organ Soc. 2016; 51: 12-28.

Publisher Full Text

Beets SD: Critical Events in the Ethics of U.S. Corporation History. J Bus Ethics. 2011; 102(2): 193-219.

Publisher Full Text

Birkinshaw J, Mol M: How management innovation happens. MIT Sloan Manag
Rev. 2006; 47(4): 81-88.

Reference Source

Blanck P: The struggle for web eQuality by persons with cognitive disabilities. Behav Sci Law. 2014; 32(1): 4-32.

PubMed Abstract | Publisher Full Text

Burnes B: Kurt Lewin and the planned approach to change: A Re-appraisal.

J Manag Stud. 2004; 41(6): 977-1002.

Publisher Full Text

Carroll AB: Corporate social responsibility: Evolution of a definitional construct. Business \& Society. Bus Soc. 1999; 38(3): 268-295.

Publisher Full Text

Cheung W, Babin G: A metadatabase-enabled executive information system (Part A): A flexible and adaptable architecture. Decis Support Syst. 2006; 42(3): 1589-1598.

Publisher Full Text

Cooper RG: Idea-to-Launch Gating Systems: Better, Faster, and More Agile: Leading firms are rethinking and reinventing their idea-to-launch gating systems, adding elements of Agile to traditional Stage-Gate structures to add systems, adding elements of Agile to traditional Stage-Gate structures to add
flexibility and speed while retaining structure. Res-Technol Manag. 2017; 60(1): flexibility

Publisher Full Text

Daft RL: Organization theory and design. (11th ed. ed.). Mason, $\mathrm{OH}$ : Cengage Learning. 2012.

Reference Source

Daft RL, Jonathan M, Willmott $\mathrm{H}$ : Organization theory and design. USA: Cengage Learning. 2010.

Dahlsrud A: How corporate social responsibility is defined: An analysis of 37 
definitions. Corp Soc Responsib Environ Manag. 2008; 15(1): 1-13. Publisher Full Text

Damanpour F: The Adoption of Technological, Administrative, and Ancillary Innovations: Impact of Organizational Factors. J Manage. 1987; 13(1): $675-688$.

Publisher Full Text

Damanpour F, Aravind D: Managerial Innovation: Conceptions, Processes, and Antecedents. Manag Organ Rev. 2011; 8(2): 423-454.

Publisher Full Text

Damanpour F, Evan WM: Organizational Innovation and Performance: The Problem of "Organizational Lag". Adm Sci Q. 1984; 29(3): 392-409. Publisher Full Text

Davila A, Foster G: Management Control Systems in Early-Stage Startup Companies. Account Rev. 2007; 82(4): 907-937.

Publisher Full Text

Denning S: Succeeding in an increasingly Agile world. Strategy \& Leadership. 2018; 46(3): 3-9.

Publisher Full Text

Dent EB, Goldberg S: Challenging "Resistance to Change". J Appl Behavioral Sci. 1999; 35(1): 25-41.

Publisher Full Text

Donald M: Organisational change factors : more than disgruntled employees or poor process. Paper presented at the AIPM 2016 Inaugral Regional Conference (Peer Reviewed Paper), Sydney, Australia. 2016.

Reference Source

Donald M: Resistance to change forms and effects in Greater Western Sydney: a multidimensional approach. (Doctor of Philosphy- Business), Western Sydney University, Sydney, Australia. 2017.

Donald M: Leading and Managing Change in the Age of Disruption and Artificial Intelligence. United Kingdom: Emerald. 2019.

Reference Source

Ekberg K, Pransky G, Besen E, et al.: New Business Structures Creating Organizational Opportunities and Challenges for Work Disability Prevention. $J$ Occup Rehabil. 2016; 26(4): 480-489.

PubMed Abstract | Publisher Full Text | Free Full Text

El-Najdawi MK, Liberatore MJ: Matrix management effectiveness: an update for research and engineering organizations. Proj Manag J. 1997; 28(1): 25-31. Reference Source

Friedman M: The Social Responsibility of Business is to Increase its Profits. New York Times Magazine, 122-126(September), 1970; 32-33.

Gebauer H, Kowalkowski C: Customer-focused and service-focused orientation in organizational structures. J Bus Ind Mark. 2012; 27(7): 527-537.

Publisher Full Text

Ghoshal S, Westney DE: Introduction and Overview. In: S. Ghoshal \& D. E. Westney (Eds.), Organization Theory and the Multinational Corporation. New York: Saint Martin's Press. 1993; 1-23.

Publisher Full Tex

Giraud F, Langevin P, Mendoza C: Justice as a rationale for the controllability principle: A study of managers' opinions. Manage Account Res. 2008; 19(1): 32-44.

Publisher Full Text

Gokpinar B, Hopp WJ, Iravani SM: The Impact of Misalignment of Organizational Structure and Product Architecture on Quality in Complex Product

Development. Manage Sci. 2010; 56(3): 468-484

Publisher Full Text

Goold M, Campbell A: Making Matrix Structures Work:: Creating Clarity on Unit Roles and Responsibility. Eur Manage J. 2003; 21(3): 351-363.

Publisher Full Text

Grabowski M, Roberts K: High reliability virtual organizations: Co-adaptive technology and organizational structures in tsunami warning systems. ACM Transactions on Computer-Human Interaction (TOCHI). 2011; 18(4): 1-23.

Grubbs KE: Profits and Prophets. World Trade. 1998; 11(3): 96.

Guadalupe M, Li H, Wulf J: Who Lives in the C-Suite? Organizational Structure and the Division of Labor in Top Management. Manage Sci. 2013; 60(4): 824-844. Publisher Full Text

Guan Y, Huang G: Empirical Study on the Influencing Factors of Business Model Innovation. Applied Mechanics and Materials. 2014; 687-691.

(Manufacturing Technology, Electronics, Computer and Information Technology Applications), 4746-4749.

Publisher Full Tex

Guthey E, Morsing M: CSR and the Mediated Emergence of Strategic Ambiguity. J Bus Ethics. 2014; 120(4): 555-569.

Publisher Full Text

Hamel G: The why, what, and how of management innovation. Harv Bus Rev. 2006; 84(2): 72-84.

PubMed Abstract

Heenan D, Perlmutter HV: Multinational Organization Development. Reading,

MA: Addison-Wesley. 1979.

Reference Source

Homburg C, Hoyer WD, Fassnacht M: Service orientation of a retailer's business strategy: dimensions, antecedents, and performance outcomes. J Mark. 2002;
66(4): 86-101

Publisher Full Text

Hu B: Linking business models with technological innovation performance through organizational learning. Eur Manage J. 2014; 32(4): 587-595. Publisher Full Text

James HS, Rassekh F: Smith, Friedman, and Self-Interest in Ethical Society

Business Ethics Quarterly. 2000; 10(3): 659-674.

Publisher Full Text

Jevtić M, Jovanović M, Krivokapić J: A new method for measuring organizational authority and accountability: Quantitative approach. Industrija. 2018; 46(3): 47-69. Publisher Full Text

Johns TG: On creating organizational support for the project management method. Int J Proj Manag. 1999; 17(1): 47-53.

Publisher Full Text

Jonsson A, Foss NJ: International expansion through flexible replication: Learning from the internationalization experience of IKEA. J Int Bus Stud. 2011 42(9): 1079-1102.

Publisher Full Text

Juras A, Brockmeier J, Niedergesaess V, et al.: Trust and team development to fight chaos: three student reports. Al Soc. 2014; 29(2): 267-275.

Publisher Full Text

Kamani A: The Case Against Corporate Social Responsibility. Wall Street Journal. 2010; (23): R1.

Reference Source

Khandwalla PN: Viable and Effective Organizational Designs of Firms. Acad

Manag J. 1973; 16(3): 481-495.

Publisher Full Text

Kim L, Utterback JM: The Evolution of Organizational Structure and Technology in a Developing Country. Manage Sci. 1983; 29(10): 1185-1197.

Publisher Full Text

Král P, Králová V: Approaches to changing organizational structure: The effect of drivers and communication. J Bus Res. 2016; 69(11): 5169-5174.

Publisher Full Text

Kuehn RR, Khandekar RP, Scott CR: The effects of marginality ad reward on matrix conflict. Proj Manag J. 1996; 27(3): 17-26.

Reference Source

Kuprenas JA: Implementation and performance of a matrix organization structure. Int J Proj Manag. 2003; 21(1): 51-62.

Publisher Full Text

Lado AA, Boyd NG, Hanlon SC: Competition, cooperation, and the search fo economic rents: A syncretic model. Acad Manag Rev. 1997; 22(1): 110-141. Publisher Full Text

Lewin K: The research center for group dynamics at Massachusetts Institute of Technology. Sociometry. 1945; 8(2): 126-136.

Publisher Full Text

Luo X, Slotegraaf RJ, Pan X: Cross-functional "coopetition": The simultaneous role of cooperation and competition within firms. J Mark. 2006; 70(2): 67-80. Publisher Full Text

Maciejczyk A: Challenges of control in functional organization structures:

Example of outsourcing sector. J Econ Manag. 2016; 25(25): 48-62.

Publisher Full Text

Manne HG: Milton Friedman Was Right. Wall Str J. 2008; (24): A12.

Reference Source

Margolis JD, Walsh JP: Misery loves companies: Rethinking social initiatives by business. Adm Sci Q. 2003; 48(2): 268-305.

Publisher Full Text

Markides C: Strategic innovation. Sloan Manage Rev. 1997; 38(3): 9-23. Reference Source

Merchant KA, Otley DT: A Review of the Literature on Control and

Accountability. Handbooks of management accounting research. 2006; 2

785-802.

Publisher Full Text

Merton R: Social Theory and Social Structure. New York: Free Press. 1968.

Reference Source

Mintzberg $\mathrm{H}$ : The structuring of organisations: A synthesis of the research.

New Jersey: University of Illinois. 1979.

Reference Source

Nisar A, Palacios M, Grijalvo M: Open organizational structures: A new framework for the energy industry. J Bus Res. 2016; 69(11): 5175-5179. Publisher Full Text

Perlmutter HV: The Tortuous Evolution of the Multinational Corporation.

Columbia J World Bus. 1969; 4(1): 9-18.

Publisher Full Text

Peters J: On structures. Management Decision. 1993; 31(6): 60

Pies I, Beckmann M, Hielscher S: Value Creation, Management Competencies, and Global Corporate Citizenship: An Ordonomic Approach to Business Ethics in the Age of Globalization. J Bus Ethics. 2010; 94(2): 265-278. Publisher Full Text

Pisano GP: Organizing for innovation. Harv Bus Rev. 1996; 74.

Porter M: What is Strategy? Harv Bus Rev. 1996; 74(6): 61-78. Reference Source 
Quail J: Becoming fully functional: The conceptual struggle for a new structure for the giant corporation in the US and UK in the first half of the twentieth century. Business History. 2008; 50(2): 127-146.

Publisher Full Text

Rapoport V: Constancy and change: Flexible organization structures. Systems practice. 1989; 2(4): 433-450.

Publisher Full Text

Romelaer P, Beddi H: Strategy and Structure in International Multi-business

Groups: Looking beyond Global Integration-Local Responsiveness. International Studies of Management \& Organization. 2015; 45(4): 359-378. Publisher Full Text

Roome N: Sustainability Strategies for Industry: The Future of Corporate Practice. Washington, DC: Island Press. 1998.

Publisher Full Text

Roome N: A Retrospective On Globalization and Sustainable Development: The Business Challenge of Systems Organization and Systems Integration. Bus Prof Ethics J. 2011; 30(3/4): 195-230.

Publisher Full Tex

Sarmiza P: New Faces of Globalization: Market Integration, Production Disintegration, Genesis of New Global Organizational Structures for Production and Trade. Revista de Economie Mondială. 2010; 2(3): 11-28. Reference Source

Schur L, Kruse D, Blanck P: People with disabilities: sidelined or mainstreamed? Cambridge: Cambridge University Press. 2013.

Reference Source

Silver D: Corporate Codes of Conduct and the Value of Autonomy. J Bus Ethics. 2005; 59: 3-8.

Publisher Full Text
Simons R: Levers of organization design: How managers use accountability systems for greater performance and commitment. USA: Harvard Business Press. 2005

Reference Source

Simons R: The Entrepreneurial Gap: How Managers Adjust Span of

Accountability and Span of Control to Implement Business Strategy. Harvard Business School Accounting \& Management Unit Working Paper No. 13-100. 2013. Reference Source

Stopford JM, Wells LT: Managing the Multinational Enterprise. New York: Basic Books. 1972.

Publisher Full Text

Strese S, Meuer MW, Flatten TC, et al: Organizational antecedents of crossfunctional coopetition: The impact of leadership and organizational structure on cross-functional coopetition. Ind Mark Manag. 2016; 53: 42.

Publisher Full Text

Stverkova H, Pohludka M: Business Organisational Structures of Global Companies: Use of the Territorial Model to Ensure Long-Term Growth. Social Sciences. 2018; 7(6).

Publisher Full Text

Vaccaro IG, Volberda HW, Van Den Bosch FAJ: Management innovation in action: the case of selfmanaging teams. In: Pitsis TS, Simpson A, Dehlin $E$ :

(Eds.), Handbook of Organizational and Managerial Innovation. Cheltenham: Edwar Elgar. 2012; 138-162.

Publisher Full Text

Virtanen M, Kivimäki M, Joensuu M, et al:: Temporary Employment and Health: A Eeview. Int J Epidemiol. 2005; 34: 610-622.

PubMed Abstract | Publisher Full Text

Williams C, McWilliams A, Lawrence R: MGMT3. (3rd ed.). Australia: Cengage Learning Australia. 2016. 


\title{
Open Peer Review
}

\section{Current Peer Review Status: $\mathrm{X}$ ?}

Version 1

Reviewer Report 15 October 2021

https://doi.org/10.21956/emeraldopenres.14788.r27759

(C) 2021 Margherita A. This is an open access peer review report distributed under the terms of the Creative Commons Attribution License, which permits unrestricted use, distribution, and reproduction in any medium, provided the original work is properly cited.

\begin{abstract}
Alessandro Margherita
University of Salento, Lecce, Italy

The topic is timely and it has a potential theoretical and practitioner relevance. However, the manuscript has limitations since it is not really focused on how the pandemic outbreak (as anticipated in the title) is having an impact on leadership and management practices. Concerning the "context" of investigation/application, the concept of "leaders" is quite broad and the study should better communicate where and for whom the contributory nature of the study can be envisioned.
\end{abstract}

The research gap is not properly documented and supported with literature and this brings to a poorly articulated research objective. The authors use a literature review but this does not appear as a real systematic review and the article does not include enough methodological details (e.g. references to SLR theory works, description of the research process undertaken). Moreover, the literature analyzed misses many relevant (recent) works on the managerial and organizational implications of the pandemic. The article does not include any paper of 2020 and 2021 and the most recent articles analyzed are of 2019 , including a work which is often mentioned in the text but is quite far from the article scope, being a review on managing change in the age of digital disruption.

The model (and related considerations) proposed is not supported with real cases or examples able to provide an illustrative representation of the findings derived from literature (how?). The contribution is thus not strong in terms of disclosing how the Covid-19 pandemic is really changing leadership and management practices. The article, in this perspective, is grounded on literature, which is not really capturing the essence of the pandemic emergence and its impact on management. Many research constructs are reported in the literature section (e.g. organizational design, globalization, corporate social responsibility) which show a limited connection (at least not properly documented) with the intended goals and outcomes of the research.

It is not really clear how the proposed model (Figure 1) was derived from literature.

Finally, the structure of the manuscript is quote atypical, and a more traditional sequence of 
sections would better help the reader understand the analytical flow, with introduction and real (documented and focused) research gap; updated literature (with pandemic-relevant works of $2019,2020,2021$ ) with a clear description of the selection and analysis criteria; methodology, with the conceptual development process and clear analysis of how the literature has supported the development of the proposed framework; obtained results; discussion of findings, also in terms of advancement respect to extant theory, theoretical and practitioner implications; conclusions, limitations and avenues for further research.

Whereas the topic is of interest for practitioners, a major revision work is required before considering the article as a scientific piece of work. Good luck with the next steps.

Is the work clearly and accurately presented and does it cite the current literature? Partly

Is the study design appropriate and is the work technically sound?

No

Are sufficient details of methods and analysis provided to allow replication by others? Partly

If applicable, is the statistical analysis and its interpretation appropriate?

Not applicable

Are all the source data underlying the results available to ensure full reproducibility? Partly

Are the conclusions drawn adequately supported by the results? Partly

Is the argument information presented in such a way that it can be understood by a nonacademic audience?

Yes

Does the piece present solutions to actual real world challenges?

No

Is real-world evidence provided to support any conclusions made?

No

Could any solutions being offered be effectively implemented in practice?

Not applicable

Competing Interests: No competing interests were disclosed.

Reviewer Expertise: Digital and organizational transformation; collective intelligence systems; corporate and technological entrepreneruship; process and project management 


\section{I confirm that I have read this submission and believe that I have an appropriate level of expertise to confirm that it is of an acceptable scientific standard, however I have significant reservations, as outlined above.}

Reviewer Report 12 March 2021

https://doi.org/10.21956/emeraldopenres.14788.r27392

(C) 2021 Romero-Ania A. This is an open access peer review report distributed under the terms of the Creative Commons Attribution License, which permits unrestricted use, distribution, and reproduction in any medium, provided the original work is properly cited.

\section{Alberto Romero-Ania}

Department of Applied Economics, Rey Juan Carlos University, Madrid, Spain

According to the abstract this manuscript studies how disruption, pandemic in particular, is changing leadership and management practices, nevertheless it does not include real cases, nor has it involved survey or interview of organisations to see what may be happening during the pandemic.

Although the title is related to the article contents, it is not enough representative. It is ambiguous and does not clarify if "leaders" are business leaders or politicians, if it applies to worldwide leaders or from one specific country or region. It would be better to specifically inform if disruption is related to disruption in general or disruption in some specific sectors or areas, as well as to clarify that the pandemic is the Covid-19 pandemic.

It is recommended to explain the manuscript organization at the end of the introduction.

The choice of the applied technique (literature review) is not well grounded.

The analysis is based on author reflection and many quotations related to leadership and business structure in general, but there is not a clear method of research to discover how Covid-19 pandemic is changing leadership and management practices.

The applied technique (literature review) is useful for giving insight into leadership and business structure in general, but it is not useful to achieve the research objective.

The main contribution of this paper is the literature review related to the general area of leadership and business structure, with extensive references to previous academic literature. It would be recommendable to avoid unnecessary self-citation and to include much more references related to the specific topic of research.

The most relevant weakness of this investigation is to be based on theories published before the pandemic instead of taking into consideration nowadays leaders perspectives and reactions to the pandemic. Literature review is adequate to explore previous theoretical background, but to analyze nowadays situation and leaders reactions is fundamental to understand how leaders can 
manage the disruption caused by the pandemic.

The abstract should clearly identify the method of research.

The abstract should clearly identify key results. In case main contribution of this research is to identify "new organisational principles to work", then it would be appropriate to specifically include those principles in the abstract, so the reader will know the concrete add value of the manuscript.

The methodology section does not provide enough information to allow other researchers to replicate the research. Research design and procedures are not clear and no research techniques have been applied, so the validity of conclusions is questionable. The conclusions of the study are not supported by appropriate evidence.

Please include research question-s and hypothesis-es.

Reflections and quotations are related to general issues so conclusions are broad including unjustified claims and generalizations.

The manuscript organization must be improved, please follow usual research article structure: 1 . Introduction (research question/s and hypothesis/es, etc.), 2. Literature review in general and discussion of specific topic of research theoretical background, 3. Methodology (data source, sample description, applied technique description, etc.), 4. Results, 5. Discussion, and 6.

Conclusions (including limitations, etc.).

Thank you very much for your efforts writing this manuscript.

Is the work clearly and accurately presented and does it cite the current literature? No

Is the study design appropriate and is the work technically sound?

No

Are sufficient details of methods and analysis provided to allow replication by others? No

If applicable, is the statistical analysis and its interpretation appropriate? Not applicable

Are all the source data underlying the results available to ensure full reproducibility? No source data required

Are the conclusions drawn adequately supported by the results? No

Is the argument information presented in such a way that it can be understood by a nonacademic audience? 
No

Does the piece present solutions to actual real world challenges?

No

Is real-world evidence provided to support any conclusions made?

No

Could any solutions being offered be effectively implemented in practice?

No

Competing Interests: No competing interests were disclosed.

Reviewer Expertise: Applied economics

I confirm that I have read this submission and believe that I have an appropriate level of expertise to state that I do not consider it to be of an acceptable scientific standard, for reasons outlined above. 